\title{
The Difference of Solvent Polarity to Qualitative and Quantitative Phytochemical Contents and Antioxidant Activity of Ficus roxburghii Wall. Leaves and Fruits Extracts
}

\author{
Pushpa Ruwali* and Sarita Pateliya
}

Department of Biotechnology, M. B. Government, P.G. College Haldwani-263139, Uttarakhand, India

*Corresponding author

\begin{tabular}{|l|}
\hline Ke y w o r d s \\
Ficus roxburghii, \\
$\begin{array}{l}\text { Extracts, } \\
\text { antioxidant, } \\
\text { Phytochemical, } \\
\text { dose-dependent }\end{array}$ \\
\hline Article Info \\
\hline $\begin{array}{l}\text { Accepted: } \\
\text { 15 March } 2019 \\
\text { Available Online: } \\
\text { 10 April } 2019\end{array}$ \\
\hline
\end{tabular}

The aim of this work was to establish the antioxidant capacity and the polyphenolic profile of important medicinal plant, Ficus roxburghii Wall. that could potentially be used in the human and animal diet. The widespread use of herbal remedies and healthcare preparations is described in the Vedas and the Bible. Medicinal Plants have been used for thousands of years to flavor and conserve food, to treat health disorders and to prevent diseases including epidemics. Active compounds produced during secondary metabolism are usually responsible for the biological properties of plant species used throughout the globe for various purposes, including treatment of infectious diseases. One such medicinally important plant Ficus roxburghii was chosen and the present study was designed to perform preliminary phytochemical analysis of various extracts of Ficus roxburghii leaves and fruits viz. methanolic (FRME), ethanolic (FRETH), chloroform (FRCHLO), hexane (FRHEX). In addition, total phenolic (TPC) and flavonoid (TFC) contents of various extracts were measured, also the various extracts were evaluated for the antioxidant capacities using most widely accepted in vitro chemical tests such as DPPH and ABTS free radical scavenging assays. The result of the preliminary phytochemical analysis revealed the presence of various phytochemical groups viz. carbohydrates, reducing sugar, tannins, phenolics, flavonoids, lignins, amino acids, saponins, glycosides, sterols, triterpenes, and alkaloids with variations among the various extracts. Results for the assays of antioxidative activity showed that all extracts exhibited significant antioxidant activities in a dose-dependent manner. The best antioxidant potential was found in Methanolic extract of $F$. roxburghii (FRME). FRME has the ability of scavenging ABTS and DPPH radicals in dose-dependent manner, to much better extent than FRCHLO, FRHEX and FRETH. This study shows that the fruit and leaf extract of Ficus roxburghii could be used as a probable antioxidative agent. The leaves of Ficus roxburghii show a more positive result in the antioxidant and phytochemical test as compared to fruits. Additional highly developed research is essential for isolation and identification of specific active components which are responsible for pharmacological properties of the plant. 


\section{Introduction}

Plants have been used for a variety of purposes since time immemorial. The history of humans clearly depicts the use of plants to treat various diseases; these plants which possess the healing properties are regarded as 'medicinal plants' or 'herbs'. Medicinal plants are distributed throughout the globe and India is quite rich in this aspect being one of the major raw material producing nations of South East Asia with the Himalayas supporting a large number of such species. Also, Uttarakhand possesses an invaluable treasure of medicinal plants holding a major share in cultivation and export (Chatterjee et al., 2014; Tandon, 1996).

The medicinal value of these plants lies in some chemical substances that produce a definite physiological action on the human body. The most important of these bioactive compounds are alkaloids, flavonoids, tannins, and phenolic compounds. Herbal medicines use these different phytoconstituents for prevention of health issues. These compounds have also provided us with valuable drugs such as analgesics (morphine), antitussives (codeine), antihypertensives (reserpine), cardiotonics (digoxin), antineoplastics (vinblastine and taxol) and antimalarials (quinine and artemisinin) (Ramawat et al., 2009).

Not only in India but the herbal drugs derived from medicinal plants are also being prescribed in Germany and France. The demand for herbal based products has steeply increased in the European Union with steady growth in the years reaching to more than 20 billion from about 6 billion in the early 1990s (Kamboj, 2000). Along with being effective, these medicinal products are comparatively cheaper. Medicinal plant drug discovery continues to provide new and important leads against various pharmacological targets including deadly diseases such as cancer, malaria, cardiovascular diseases and neurological disorders (Ramawat et al., 2009).

A free radical is an atom or a molecule that has an unpaired valence electron and is capable of independent existence (Halliwell and Gutteridge, 1999). Radicals are constantly generated in a living system and being highly chemically reactive they damage the biomolecules and tissues leading to various disease conditions especially degenerative disease and extensive lysis. Antioxidants are compounds that prevent the making of free radicals by inhibiting the process of oxidation. As a result antioxidants such as thiols, ascorbic acid and polyphenols are considered as reducing agents (Sies, 1997). It has been proven in the past few decades that a diet rich in antioxidants such as vitamin $\mathrm{C}, \mathrm{E}$ or flavonoids, tannins, phenolics, and terpenoids can prevent oxidative stress and specific human diseases (Perumalla et al., 2011).

\section{Ficus roxburghii (Timal)}

Ficus roxburghii Wall. commonly known as 'Timal' in Hindi and 'Elephant ear fig' in English is a medicinal plant belonging to the family of Moraceae (Khan, 2001). The genus Ficus consists of about 800 species in 40 genera of this family (Adebayo et al., 2009; Chawla et al., 2012). Ficus roxburghii is one of the widely distributed species of genus Ficus and is native to India, Pakistan, China, Bhutan, Malaysia, Myanmar, Nepal, Thailand, and Vietnam. It gives pear-shaped and reddish-brown color fruits, hanging on peduncles $2.5 \mathrm{~cm}$ or more (Kala, 2007; Thinbaijam et al., 2012).

A number of Ficus species are used as food and for medicinal purposes in ayurvedic and traditional Chinese medicine to treat several common ailments as well as its extracts also 
contain a wide range of active ingredients such as phenolic compounds, flavonoids, alkaloids, sterols, glycosides, saponins, and carbohydrates and justifying their usage in food systems. Most of these phytoconstituents are mainly responsible for strong antioxidant properties that help in the prevention and treatment of various oxidative stress-related diseases such as neurodegenerative and hepatic diseases (Gaire et al., 2011; Salem et al., 2013; Achi et al., 2017).

The roasted fruit as well as the juice of this plant followed by intake of warm saline water is employed in the treatment of diarrhea and dysentery (Khan, 2001) also the fruit extract does contain anti-tumor activity (Aswar et al., 2008). It is also stated that the gastrointestinal problems can be treated by using $50-100 \mathrm{ml}$ fresh juice of leaves with water for about 10 days (Rout et al., 2009).

The use of Ficus roxburghii in the treatment of diarrhea, dysentery, cuts, wounds, mumps, cholera, jaundice, etc has been found to be effective (Gairola and Biswas, 2008). Also, the latex from the stem is used in treating cuts and wounds whereas the latex from roots is used in the treatment of mumps, diarrhea, and vomiting (Devkota and Karmacharya, 2003). also it has a blood-boosting effect (Otitoju et al., 2014; Njoku-oji et al., 2016), anti-sickling (Umeokoli et al., 2013; Mpiana et al., 2008) antibacterial (Oyeleke et al., 2008), antiabortifacient (Owolabi et al., 2009), immunestimulatory (Daikwo et al., 2012), antidiarrhoea (Owolabi, 2013; Manandhar, 1991), antioxidant (Ramde-Tiendrebeogo et al., 2012) and pro-fertility in treating azoospermia (Gelfand et al.,1985; Akomolafe et al., 2016). Bark and root show hypoglycaemic and anthelmintic activity (Mazumder et al., 2009; Ghosh et al., 2004). Leaves exhibit hypotensive activity (Buniyamin et al., 2007). The plant is not only used as a medicine but its fruit is used for making jams and curries as the ripened fruit is a good source of nutrients including minerals, carbohydrates, proteins, and lipids (Thingbaijam et al., 2012). In some parts of Himachal Pradesh, the unripe fruit is included in the diet in the form of vegetable. All the major parts of the plant including leaves, root, fruit as well as latex are of great importance and are a hub of cure to various diseases (Pant et al., 2009).

Taking into consideration the vast potentiality of plants as sources for antioxidants, a systematic investigation was undertaken to screen the local flora of Kumaun for its radical scavenging activity so the main aims of this study were to investigate the effect of four solvent extracts viz. Methanolic (FRME), Ethanolic (FRETH), Chloroform (FRCHLO), Hexane (FRHEX) on phytochemical contents of Ficus roxburghii leaves and fruits and then to evaluate their effect on antioxidant properties by using most widely accepted in vitro tests such as DPPH and ABTS radical scavenging activities. In addition, total phenolic (TPC) and flavonoids (TFC) contents of various extracts were measured. The TPC was determined using the FolinCiocalteu method while TFC was determined using aluminium chloride method.

\section{Materials and Methods}

\section{Chemicals}

All chemicals, reagents, and solvents were of the analytical grade obtained from S.D. Fine Chemical Pvt. Ltd., Mumbai and Hi Media Laboratories Pvt. Ltd, Mumbai, India.

\section{Collection of plant material}

Fresh leaves and fruits of Ficus roxburghii Wall. specimens were collected from Haldwani, Nainital district of Uttarakhand state (India) in the month of February 2018, 
strictly abiding by the standard precautions. The collected plant was identified at the Department of Botany, DSB Campus, Kumaun University, Nainital.

\section{Processing of the plant material}

The leaves and fruits samples were thoroughly washed, dried, and ground into fine homogeneous powder and were kept in sealed polyethylene bags in a refrigerator at $4^{\circ} \mathrm{C}$ till further use. The leaves and fruits samples have been indicated as Ficus roxburghii leaves (FRL) and Ficus roxburghii fruits (FRF), respectively.

\section{Extract preparation using various extracts}

The powdered leaves and fruits of Ficus roxburghii Wall. were extracted with different solvents like methanol, hexane, chloroform, and ethanol. The herb to solvent ratio was kept 1:10 to ensure complete extraction.

The plant material was extracted by cold maceration for 72 hours with the respective solvent with intermittent agitation. After incubation, the extracts were filtered through Whatman@ filter paper (Grade 1) and the extracts were collected and stored at $4^{\circ} \mathrm{C}$ in the refrigerator in an airtight container till further use (Ahuja et al., 2011).

\section{Percentage yield calculation of various extracts}

The percentage yield of various extracts of Ficus roxburghii was calculated from the product that was obtained after complete evaporation of the respective solvents as per the following formula (Ruwali et al., 2015).

\section{Percentage Yield $=\left(\mathrm{W}_{\mathrm{E}} \div \mathrm{W}_{\mathrm{S}}\right) \times 100$}

Where $\left(\mathrm{W}_{\mathrm{E}}=\right.$ weight of the plant extract; $\mathrm{W}_{\mathrm{S}}=$ Weight of the initial sample)
Preliminary phytochemical screening of various extracts of Ficus roxburghii Wall

Major phytochemical group's viz., carbohydrates, reducing sugars, amino acids, saponins, glycosides, flavonoids, tannins, sterols, triterpenes, and phenols were traced in different solvent extracts of FRL and FRF following standard procedures (Harborne, 1973; Sofowara, 1982; Ruwali et al., 2015).

Quantitative phytochemical analysis of various extracts of Ficus roxburghii Wall

\section{Total phenolic content}

The amount of phenol in the aqueous extract was determined by the Folin-Ciocalteu reagent method with some modifications (Singleton and Rossi, 1965). The calibration curve was prepared by mixing different solutions of Gallic acid $(1 \mathrm{ml} ; 20-120 \mu \mathrm{g} / \mathrm{ml})$ with $5 \mathrm{ml}$ of Folin-Ciocalteu reagent (tenfold diluted) and $4 \mathrm{ml}$ of $\mathrm{Na}_{2} \mathrm{CO}_{3}$ (7.5\%). The absorbance of the sample was measured at $765 \mathrm{~nm}$. Gallic acid was used as standard $(1 \mathrm{mg} / \mathrm{ml})$. All the tests were performed in triplicates. The results were determined from the standard curve and were expressed as mg Gallic acid equivalent (GAE)/gm of the dried extract.

\section{Total flavonoid content}

Flavonoid contents were measured by the aluminium chloride colorimetric assay described by (Zhishen et al., 1999) with slight modifications (Ruwali et al., 2015). For this, $1 \mathrm{ml}$ of plant extract or standard solution of Quercetin $(20-120 \mu \mathrm{g} / \mathrm{ml})$ was added to $10 \mathrm{ml}$ volumetric flask containing $4 \mathrm{ml}$ of TGDW, followed by addition of $0.3 \mathrm{ml} 5 \% \mathrm{NaNO}_{2}$. After $5 \mathrm{~min}, 0.3 \mathrm{ml}$ of $10 \% \mathrm{AlCl}_{3}$ was added. At $6^{\text {th }} \mathrm{min}, 2 \mathrm{ml}$ of $1 \mathrm{M} \mathrm{NaOH}$ was added and the total volume was made up to $10 \mathrm{ml}$ with TGDW. The solution was mixed well and the 
absorbance was measured against prepared reagent blank at $510 \mathrm{~nm}$. TFC was expressed as mg Quercetin equivalent (QE)/gm of plant dried extract.

\section{Antioxidant activity of various extracts of} Ficus roxburghii Wall

Analysis of the antioxidant activity of various extracts of Ficus roxburghii was done by performing DPPH and ABTS free radical scavenging assays, as per standard protocols.

\section{DPPH free radical scavenging assay}

The antioxidant activity of the extracts was measured on the basis of the scavenging activity of the stable DPPH free radical according to the method described by (BrandWilliams et al., 1995) with slight modifications. $1 \mathrm{ml}$ of $0.2 \mathrm{mM}$ DPPH solution in methanol was mixed with $1 \mathrm{ml}$ of plant extract solution of varying concentrations (25, 50, 100, 200 and $400 \mu \mathrm{g} / \mathrm{ml})$. The Corresponding blank sample was prepared and Quercetin in different concentration was used as the reference standard. The reaction was carried out in triplicate and the decrease in absorbance was measured at $517 \mathrm{~nm}$ after 30 minutes in dark using UV-Vis spectrophotometer. The inhibition \% was calculated using the following formula.

\section{$\%$ Inhibition $=[(\mathrm{Ac}-\mathrm{As}) \div \mathrm{Ac}] \times 100$}

Where - 'Ac' is the absorbance of the control; 'As' is the absorbance of the sample

\section{ABTS Free Radical Scavenging Assay}

For ABTS assay, the procedure followed was the method of ( $\operatorname{Re}$ et al., 1999) with slight modifications. ABTS radical cation $\left(\mathrm{ABTS}^{+}\right)$ was obtained by reacting $\mathrm{ABTS}^{+}$stock solution with $2.45 \mathrm{mM}$ potassium persulfate (final concentration) $(1 / 1, \mathrm{v} / \mathrm{v})$ and allowing the mixture to stand in the dark for 12-16 hours (hrs) before use. The ABTS+ solution was diluted with ethanol to an absorbance of $0.700 \pm 0.05$ at $734 \mathrm{~nm}$ for measurements. The photometric assay was conducted on $0.9 \mathrm{ml}$ of ABTS $^{+}$solution and $0.1 \mathrm{ml}$ of sample extract of various concentrations and mixed for 45 sec; measurement was taken immediately at $734 \mathrm{~nm}$ after $15 \mathrm{~min}$.

The scavenging activity was estimated based on the percentage of ABTS radicals scavenged by the following formula:

$\%$ Inhibition $=[(\mathrm{Ac}-\mathrm{As}) \div \mathrm{Ac}] \times 100$

Where- 'Ac' is absorption of control; 'As' is absorption of tested extract solution.

\section{Statistical analysis}

Statistical analysis was carried out using Windows Excel 2007.All the experiments were done in triplicates. The experimental results are expressed as mean $\pm \mathrm{SD}$ of triplets. The half-maximal inhibitory concentration $\left(\mathrm{IC}_{50}\right)$ value was calculated using the linear regression analysis.

\section{Results and Discussion}

Plant phytochemicals have been reported to prolong life by their protections against numerous human health and metabolic conditions. Ficus roxburghii Wall. plant, being a potential source of bioactive compounds, has the ability to ameliorate various lifestyle-related diseases. Ficus species are a rich source of polyphenolic compounds, flavonoids which are responsible for strong antioxidant properties that help in the prevention and treatment of various oxidative stress-related diseases such as neurodegenerative and hepatic diseases. In the present study, leaves and fruit extracts from Ficus were analysed for their phytochemical 
and antioxidant properties. The purpose of this work was to perform phytochemical screening and to determine the correlation between total phenolic contents and antioxidant activities performed by ABTS assay and DPPH assay of different solvent extracts from fruits and leaves of Ficus roxburghii.

\section{Extraction yield}

The yield of crude extracts from the leaves and fruits of Ficus roxburghii, obtained by maceration method using different type of solvents (methanol, ethanol, hexane and chloroform), and was calculated (Ruwali et al., 2015). The yields of soluble substances, expressed as in percentage in leaves and fruits of Ficus roxburghii are closely dependent on the solvents, as shown in Figure 1. The variation in the yields of extracts could be attributed to the difference in solvent polarities used which also plays a key role in increasing the solubility of phytochemical compounds (Silva et al., 2014; Naima et al., 2015). Differences in the structure of phytochemical compounds also determine their solubility in solvents of different polarity (Felhi et al., 2016a).

As evident in the Figure 1, the Methanolic extract of both leaves and fruits gave the highest yield (15.36\%), (14\%) respectively, followed by Chloroform extract (13\%), (11.71\%), Hexane extract $(11.61 \%),(9.83 \%)$ and least in Ethanolic extract (10.67\%), (8) respectively. Figure 1 shows that the percentage yields for leaves and fruits with methanolic extract were better than other solvents. In the present study, we also observed variation in \% yield of solvent extracts of FRL and FRF.

\section{Preliminary phytochemical analysis}

Qualitative phytochemical tests were carried out to identify some bioactive components of the extracts. Phytochemical screening helps to reveal the chemical nature of the constituents of the plant extract. It may also be used to search for bioactive agents that could be used in the synthesis of very useful drugs (Sofowora, 1993; Yakubu et al., 2005).

The phytochemical screening of various parts (leaves and fruits) of Ficus roxburghii, showed the great presence of tannins, flavonoids, saponins, sterols, triterpenes, glycosides, reducing sugars and alkaloids and the results observed are depicted in Table 1.

Phytochemicals are biologically active, naturally occurring chemical compounds found in plants, which provide health benefits (Hasler and Blumberg, 1999). In general, the plant chemicals that protect plant cells from environmental hazards such as pollution, stress, drought, UV exposure and pathogenic attack are called phytochemicals. Recently, it is clearly known that they have roles in the protection of human health when their dietary intake is significant (Mathai, 2000).

The phytochemical screening revealed the presence of carbohydrates, alkaloids, reducing sugar, saponins, and flavonoids in all four solvents viz. methanol, ethanol, hexane, and chloroform extracts of both leaves and fruits. Lignin and amino acids were present in methanol, chloroform and hexane extracts of both leaves and fruits but were absent in ethanolic extracts. Tannins were found to be present in methanolic extracts of both fruits and leaves. Triterpenes absent in chloroform extracts of leaves, whereas present in all extracts of fruits except hexane extracts. Sterol absent in hexane extracts of both leaves and fruits, whereas present in all three extracts. In ethanolic extract of FRL phenolic compounds are absent and in hexane and ethanolic extracts of FRF, the phenolic compounds are also absent. Plant extracts revealed the presence of phytochemicals such as phenols, tannins, flavonoids, saponins, 
glycosides, steroids, terpenoids, and alkaloids, which are known to exhibit medicinal as well as physiological activities.

Flavonoids are referred to as nature's biological response modifiers because of their inherent ability to modify the body's reaction to allergens, viruses, and carcinogens. They show anti-allergic, anti-inflammatory, antimicrobial and anticancer activity (Rauha et al., 2000; Cushnie and Lamb, 2005; Spencer and Jeremy, 2008). Saponins also inhibit cancer tumour growth in animals, particularly, lung and blood cancers, without killing normal cells. Saponins are the plant's immune system acting as an antibiotic to protect the plant against microbes and fungus (Chatterrjee and Chakravorty, 1993). Carbohydrates play a major role in promoting health fitness, from a major part of a food and help a great deal in building body strength, by generating energy (David and Michael, 2006).

\section{Total phenolic contents}

Phenolic compound possesses biological properties such as apoptosis, anti-aging, anticarcinogen, anti-inflammation, antiatherosclerosis, cardiovascular protection and improvement of endothelial function, as well as inhibition of angiogenesis and cell proliferation activities. Some phenolic compounds present in natural products have higher antioxidant activities than those of synthetic antioxidants (Ruwali et al., 2017).

Polyphenolics, on reaction with FolinCiocalteu reagent under basic conditions dissociate to form a phenolate anion, which reduces molybdate in Folin-Ciocalteu reagent forming a blue colored molybdenum oxide with maximum absorption near $765 \mathrm{~nm}$. The intensity of the blue colored complex is proportional to the amount of polyphenolic compounds present in the sample (Huang et al., 2005).
The total phenolics of various extracts were assessed and expressed as mg GAE/gm of the dry weight of the extract. The content of phenolics varied among different extracting solvents used. The result of total phenolics of Ficus roxburghii leaves and fruits in various extracts are summarized in Figure 2 as (mg $\mathrm{GAE} / \mathrm{gm}$ of the dry weight of the extract).

Methanolic extract has the highest phenolic content in both leaves and fruits, followed by Chloroform, followed by Hexane and least in Ethanolic extract. Thus the TPC of leaves has high phenolic content as compared to fruits.

\section{Total flavonoid concentration}

Flavonoids are the most common group of plant polyphenols. Different studies have shown that these compounds are used for the prevention and cure of many diseases. They are capable of effectively scavenging the reactive $\mathrm{O}_{2}$ species because of their phenolic hydroxyl groups and so they are potent antioxidants also (Cao et al., 1997). Regular intake of flavonoids has reduced the risk of acute as well as a chronic disease like cancer, cardiovascular disease, and inflammatory responses.

Flavonoids protect plants against UV damage, which, to some extent, results from the fact that they can act as a screen absorbing UV radiation and, as they are accumulated mainly in the epidermis and hypodermis of leaves and stems, apical meristem and pollen, reducing the penetration of UV light to the vulnerable tissues or organs. Besides UV absorption, flavonoid compounds may also transfer or accept light energy to or from other molecules via sensitization (Sisa et al., 2010).

From this (Fig. 3) data, the result of total flavonoids of Ficus roxburghii leaves and fruits in the various extracts is summarized. 
Methanolic extract has the highest flavonoid content in both leaf and fruit, followed by Chloroform, and followed by Hexane and least in Ethanolic extract. Thus the leaves have high flavonoid content as compare to fruits.

\section{In vitro Antioxidant activity of various extracts of Ficus roxburghii}

Antioxidant activity of various extracts of Ficus roxburghii was assessed by standard and currently most accepted methods viz. DPPH stable free radical scavenging assay and the ABTS radical scavenging assay.

\section{DPPH free radical scavenging activity of} various extracts of Ficus roxburghii.

DPPH is one of the free radicals widely used for testing preliminary radical scavenging activity of the plant extract (Bhuiyan et al., 2009). Antioxidants either transfer an electron or a hydrogen atom to DPPH, thus neutralizing its free radical character (Pan et al., 2008). DPPH test, which is based on the ability of DPPH, a stable free radical, to decolorize in the presence of antioxidants, is a direct and reliable method for determining radical scavenging action (Hasan et al., 2009).

The reducing capacity of DPPH radical could serve as an indicator of potential antioxidant property (Meir et al., 1995). Substances which are able to perform this reaction can be considered as antioxidants and therefore radical scavenges. It was found that the radical scavenging activities of extract increased with increasing concentration (Ruwali et al., 2017).

The antioxidant potential of various concentrations $(\mu \mathrm{g} / \mathrm{ml})$ of Quercetin as well as various extracts of Ficus roxburghii is expressed as percent (\%) inhibition and depicted in the Figure 4 and 5. In case of
Methanolic, Chloroform, Hexane and Ethanolic extract, $400 \mu \mathrm{g} / \mathrm{ml}$ concentration showed maximum DPPH radical scavenging activity followed by $200 \mu \mathrm{g} / \mathrm{ml}, 100 \mu \mathrm{g} / \mathrm{ml}$, $50 \mu \mathrm{g} / \mathrm{ml}$ and $25 \mu \mathrm{g} / \mathrm{ml}$ show the least activity.

The amount of antioxidant activity present in leave and fruit solvents are in the order of, Quercetin > Methanol > Chloroform > Hexane > Ethanol. These scavenging activities are most probably and mostly due to the presence of the various phenolic compound.

The antioxidant activity of the sample is evaluated from the determination of $\mathrm{IC}_{50}$ values corresponding to the amount of extracts required to scavenging $50 \%$ of DPPH radicals present in the reaction mixture. Lower $\mathrm{IC}_{50}$ values indicate higher radical scavenging ability (Table 2 ).

The results of the present study showed that among various extracts, the lowest $\mathrm{IC}_{50}$ value was of methanolic extract and highest $\mathrm{IC}_{50}$ value was of ethanolic extract of $F$. roxburghii of both the plant parts used (leaf and fruit). The $\mathrm{IC}_{50}$ value of leaf extracts is less than the $\mathrm{IC}_{50}$ value of fruit extracts. This indicates that the leaves of Ficus roxburghii can be a good source of natural antioxidants.

\section{ABTS free radical scavenging activity of various extracts of Ficus roxburghii}

According to (Silva et al., 2012) the ABTS assay is based on the generation of chromophore cationic radical obtained from the oxidation of ABTS by potassium persulfate. ABTS radical scavenging method is a common spectrophotometric procedure for determining the antioxidant capacities of plants. The ABTS method is easy to use, has high sensitivity, and allows for rapid analyses of the antioxidant activity of a larger number of samples. In the ABTS test, 2, 2'-azinobis 
(3-ethylbenzthiazoline- 6- sulfonic acid) (ABTS) is converted into its radical cation $\left(\mathrm{ABTS}^{+}\right)$by addition of sodium per sulphate. This blue-green radical cation absorbs light at $734 \mathrm{~nm}$. ABTS is reactive towards most antioxidants. It is not affected by ionic strength, and it can be used to determine both hydrophilic and hydrophobic antioxidant capacities. During this reaction, the bluegreen ABTS radical cation is converted back into its colourless neutral form (Debnatha et al., 2011). In case of methanolic, ethanolic, hexane and chloroform extracts, $400 \mu \mathrm{g} / \mathrm{ml}$ concentration of crude extract show maximum activity followed by $200 \mu \mathrm{g} / \mathrm{ml}$, $100 \mu \mathrm{g} / \mathrm{ml}, 50 \mu \mathrm{g} / \mathrm{ml}$ and $25 \mu \mathrm{g} / \mathrm{ml}$ (Fig. $6 \&$ 7).

The amount of ABTS free radical scavenging activity in solvents were in the order of, Ascorbic acid > Methanol > Chloroform > Hexane $>$ Ethanol. The results are indicative of that the methanolic, chloroform, hexane, and ethanolic extracts of leaves and fruits of Ficus roxburghii are efficient free radical scavenging. Among the four extracts of both leaves and fruits tested, methanolic extracts possessed maximum radical scavenging activity, followed by chloroform, hexane and ethanolic extracts respectively. Table 3 shows the significant decrease in the concentration of ABTS radical due to the scavenging ability of the Ficus roxburghii. The results of the present study showed that among all extracts, the lowest $\mathrm{IC}_{50}$ value was of methanolic extract of $F$. roxburghii leaves and fruits and highest $\mathrm{IC}_{50}$ value was of ethanolic extract of $F$. roxburghii leaves and fruits. The $\mathrm{IC}_{50}$ value of leaves extracts is less than the $\mathrm{IC}_{50}$ value of fruits extracts. This indicates that the leaves of Ficus roxburghii can be a good source of natural antioxidants. Various solvents having different polarities were employed for the extraction of antioxidant components present in Ficus roxburghii leaves and Fruits. Our study confirms the difference in the extraction efficiency of the various solvents, which suggests that the solvent effect should be taken into account while addressing the antioxidant potential of any sample. From this study, a suggestion regarding the use of methanol for the extraction can be made, if Ficus roxburghii leaves and fruits are to be used as functional food or medicine.

Table.1 Preliminary phytochemical tests for various solvent extracts of $F$. roxburghii (FRL/FRF)

\begin{tabular}{|c|c|c|c|c|c|c|c|c|}
\hline \multirow{2}{*}{$\begin{array}{l}\text { Phyto chemicals } \\
\text { Group }\end{array}$} & \multicolumn{4}{|l|}{ FRL } & \multicolumn{4}{|l|}{ FRF } \\
\hline & FRME & FRCHLO & FRHEX & FRETH & FRME & FRCHLO & FRHEX & FRETH \\
\hline Carbohydrates & + & + & + & + & + & + & + & + \\
\hline Reducing sugar & + & + & + & + & + & + & + & + \\
\hline Tannins & + & - & - & - & + & - & - & - \\
\hline Phenolic & + & + & + & - & + & + & - & - \\
\hline Flavonoids & + & + & + & + & + & + & + & + \\
\hline Lignin & + & + & + & - & + & + & + & - \\
\hline Amino acid & + & + & + & - & + & + & + & - \\
\hline Saponins & + & + & + & + & + & + & + & + \\
\hline Glycosides & + & - & - & - & - & - & - & - \\
\hline Sterols & + & + & - & + & + & + & - & + \\
\hline Triterpenes & + & + & - & + & + & - & + & + \\
\hline Alkaloids & + & + & + & + & + & + & + & + \\
\hline
\end{tabular}

+Indicates the presence; -indicates the absence, FRL: Ficus roxburghii Leaves, FRF: Ficus roxburghii Fruits, FRME: Methanolic extract, FRCHLO: Chloroform extract, FRHEX: Hexane extract, FRETH: Ethanolic extract 
Table.2 IC50 of various solvent extracts (DPPH assay)

\begin{tabular}{|l|l|l|}
\hline Sample & IC $_{\mathbf{5 0}}$ value $(\boldsymbol{\mu g} / \mathbf{m l})$ FRL & IC $_{\mathbf{5 0}}$ value $(\boldsymbol{\mu g} / \mathbf{m l})$ FRF \\
\hline Methanol & $112.74 \pm 1.35$ & $181.55 \pm 0.46$ \\
\hline Chloroform & $120.33 \pm 0.26$ & $224.17 \pm 0.67$ \\
\hline Hexane & $128.96 \pm 1.02$ & $225.06 \pm 1.74$ \\
\hline Ethanol & $271.14 \pm 0.32$ & $278.2 \pm 0.23$ \\
\hline Ascorbic acid & $111.62 \pm 0.53$ & $156.41 \pm 0.58$ \\
\hline
\end{tabular}

Table.3 IC50 value of various solvent extracts (ABTS assay)

\begin{tabular}{|l|l|l|}
\hline Sample & IC $_{\mathbf{5 0}}$ Value $(\boldsymbol{\mu g} / \mathbf{m l})$ FRL & IC $_{\mathbf{5 0}}$ Value $(\boldsymbol{\mu g} / \mathbf{m l}) \mathbf{F R F}$ \\
\hline Methanol & $115.23 \pm 0.71$ & $151.32 \pm 0.14$ \\
\hline Chloroform & $118.72 \pm 1.41$ & $152.17 \pm 2.12$ \\
\hline Hexane & $122.24 \pm 1.52$ & $210.92 \pm 0.98$ \\
\hline Ethanol & $189.76 \pm 0.89$ & $217.51 \pm 2.02$ \\
\hline Ascorbic acid & $114.5 \pm 0.47$ & $149.18 \pm 1.01$ \\
\hline
\end{tabular}

Fig.1 Percentage yield of various solvent extracts of Ficus roxburghii (FRL/FRF)

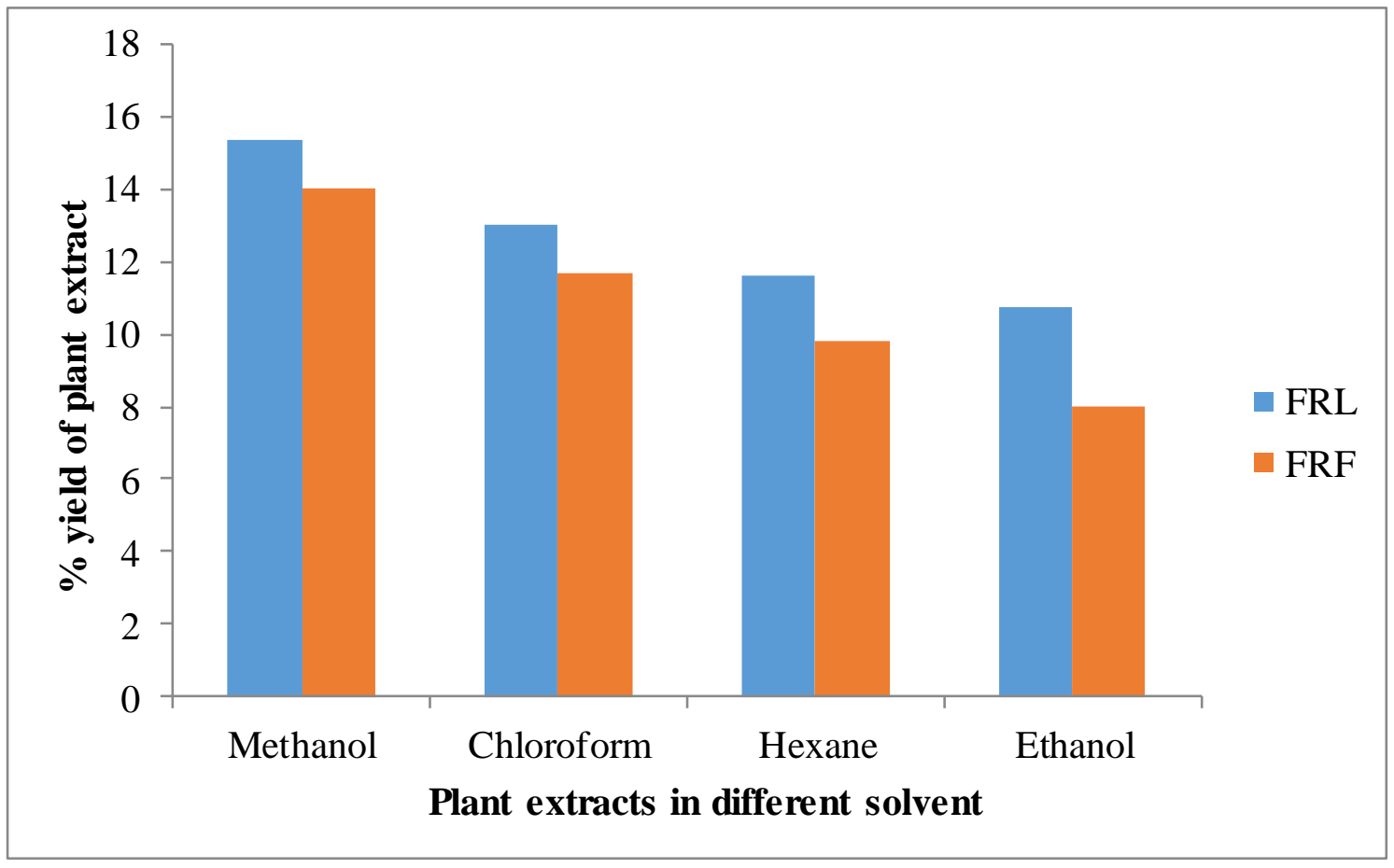


Fig.2 Total phenolic content of various extracts of Ficus roxburghii (FRL/FRF). values expressed are mean \pm standard deviation $(n=3)$

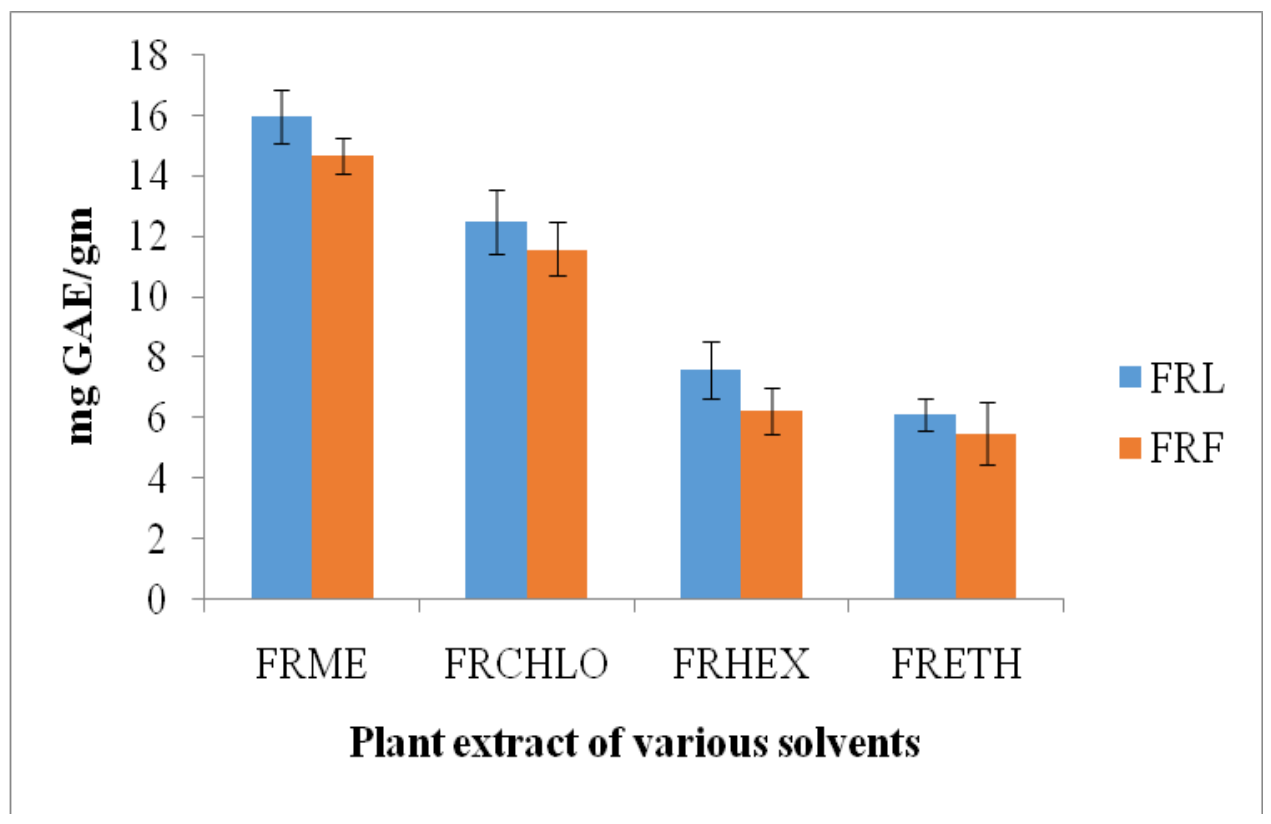

Fig.3 Total flavonoid content of Ficus roxburghii (FRL/FRF). values expressed are mean \pm standard deviation $(\mathrm{n}=3)$

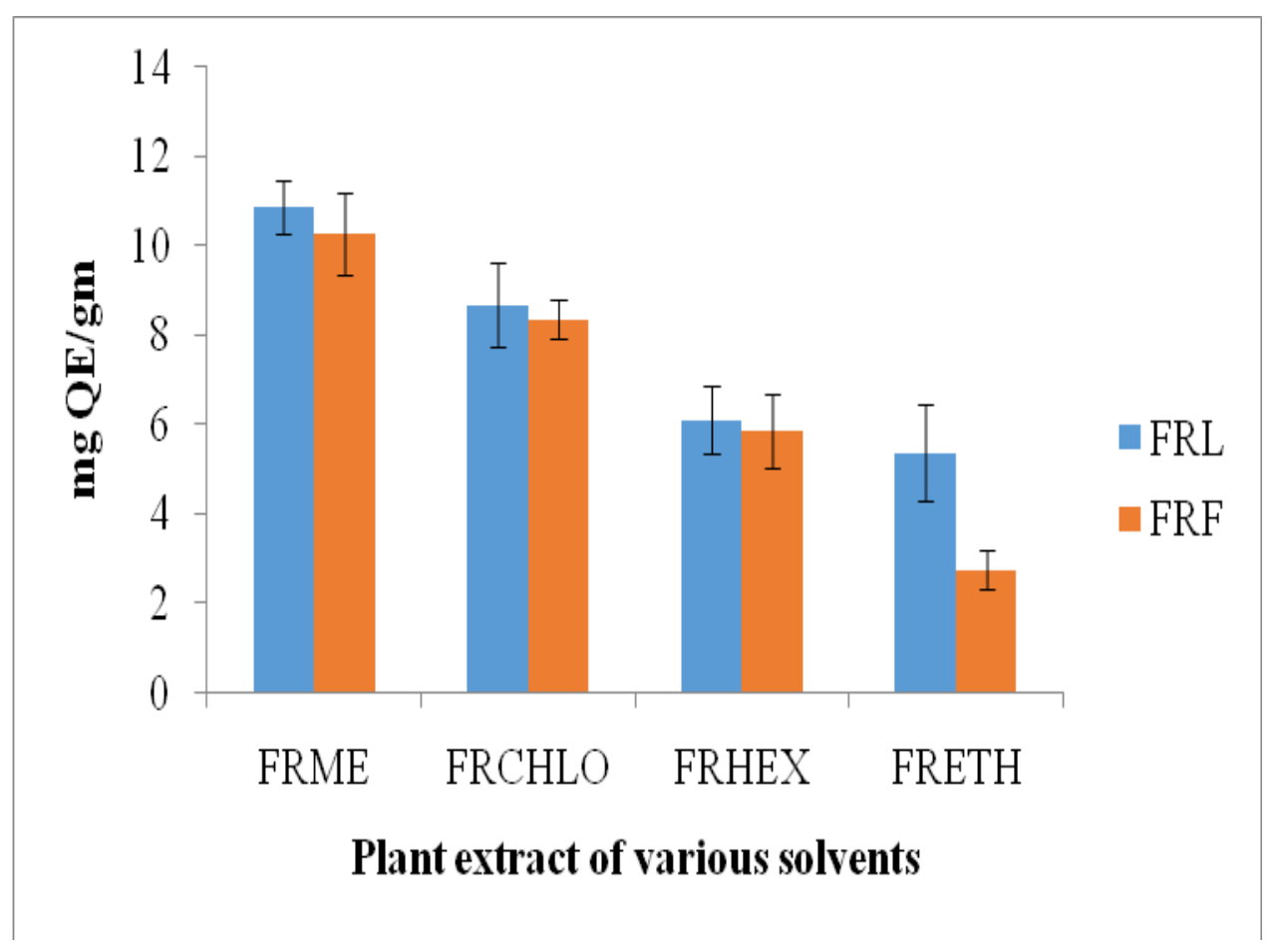


Fig.4 DPPH free radical scavenging activity of various extracts of FRL and Ascorbic acid. values expressed are mean \pm standard deviation $(n=3)$

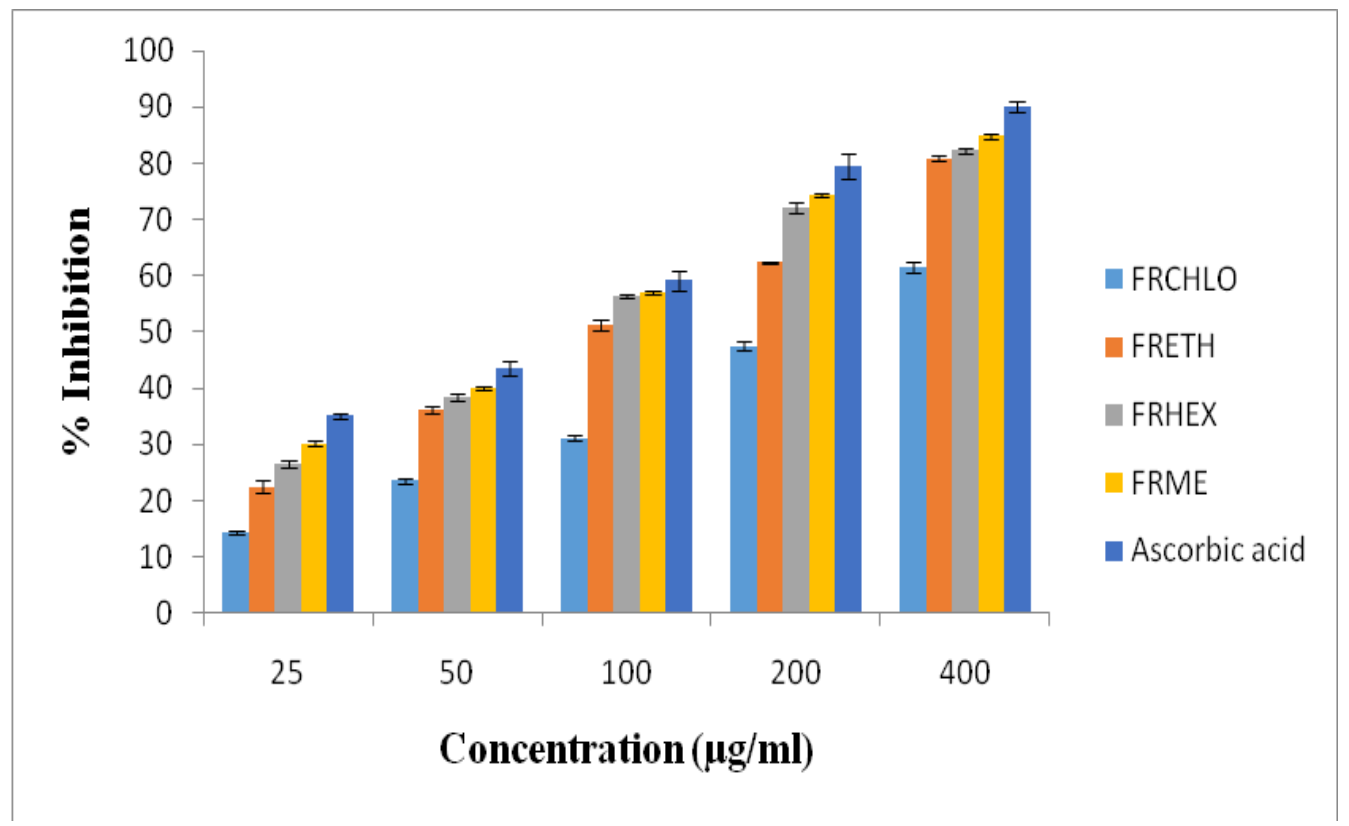

Fig.5 DPPH free radical scavenging activity of various extracts of FRF and Ascorbic acid. values expressed are mean \pm standard deviation $(n=3)$

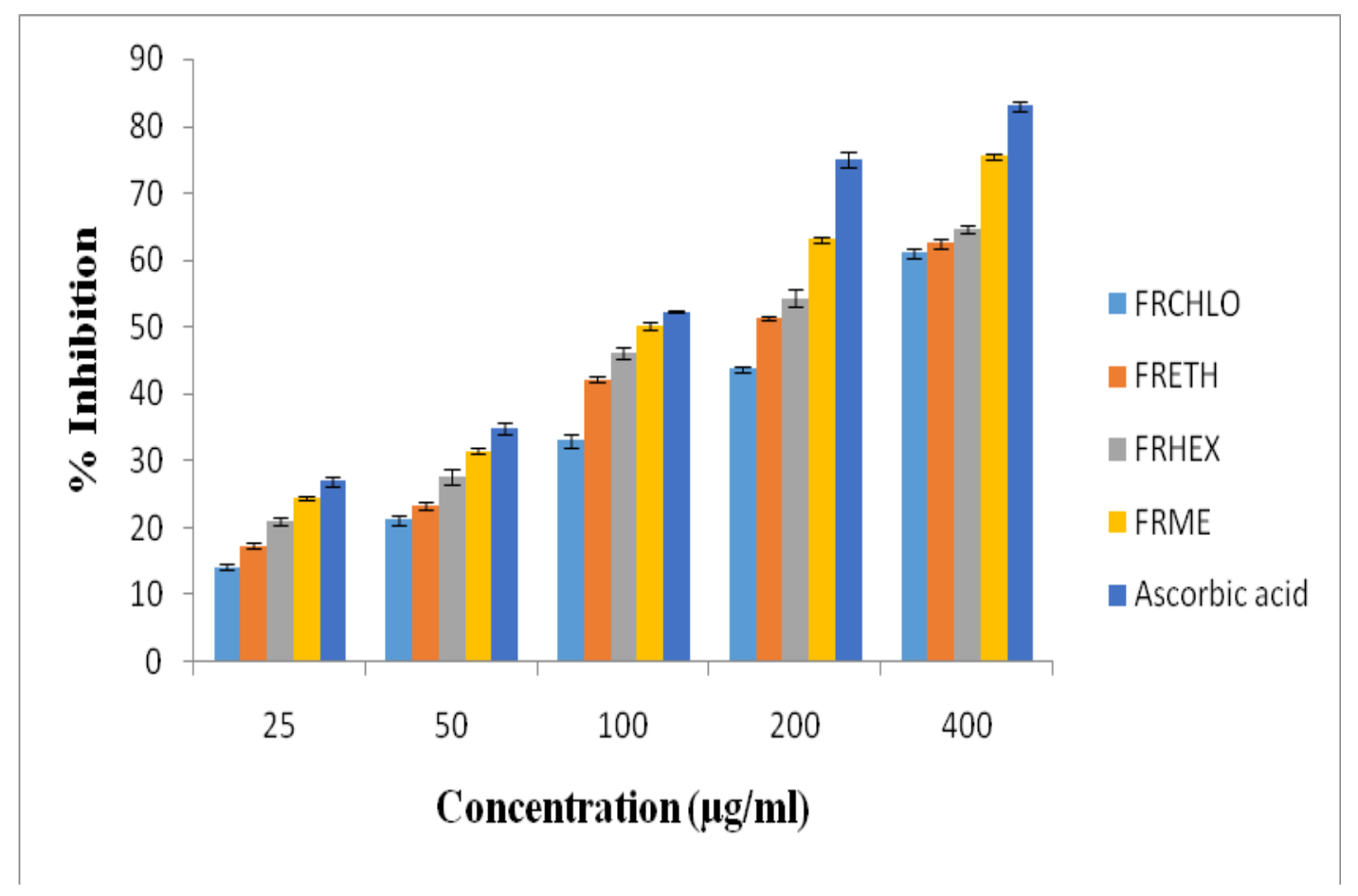


Fig.6 ABTS free radical scavenging activity of various extracts of FRL and Ascorbic acid. values expressed are mean \pm standard deviation $(n=3)$

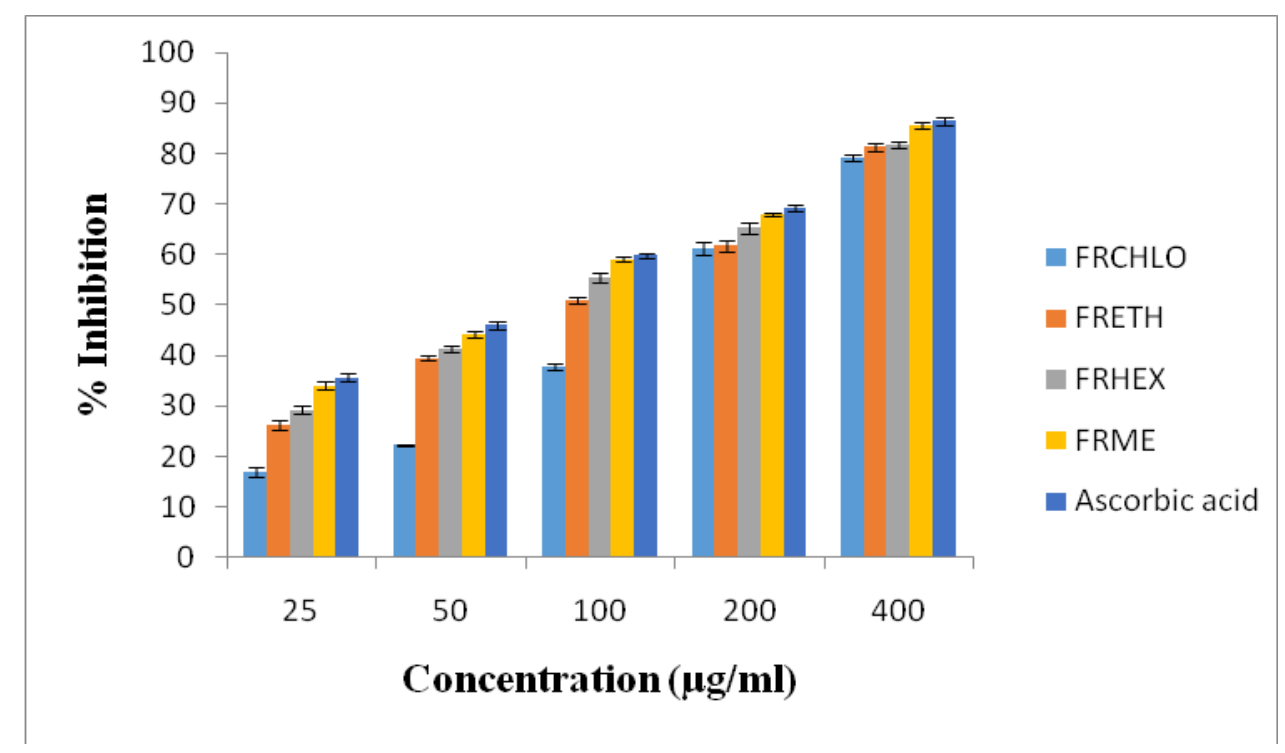

Fig.7 ABTS free radical scavenging activity of various extracts of FRF and Ascorbic acid values expressed are mean \pm standard deviation $(n=3)$

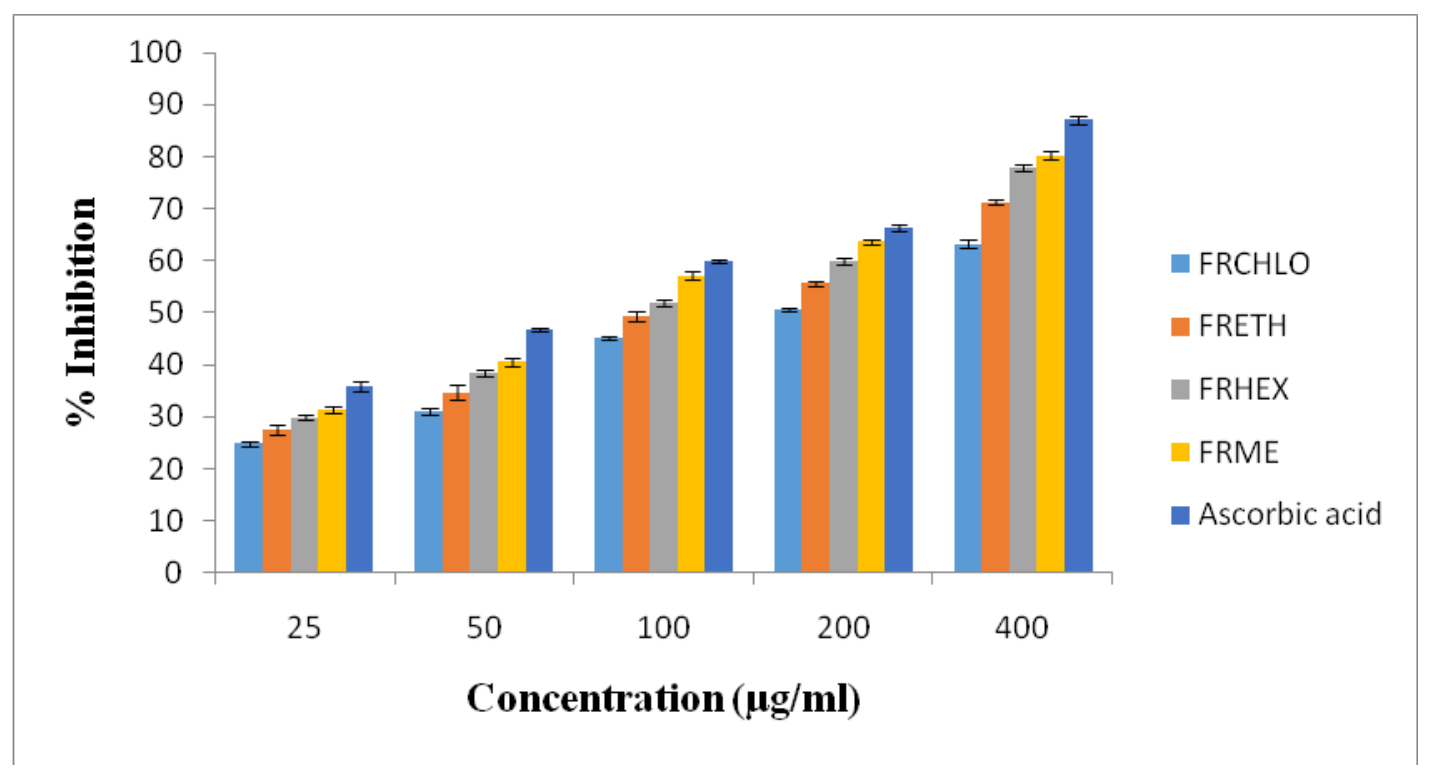

The evaluation of antioxidant competency of Ficus roxburghii leaves, Fruits by means of different assays recommends the use of this plant as nutraceuticals. The results indicated that the different part of Ficus roxburghii Wall. could be a potential natural source of antioxidants and may have greater importance as a natural antioxidant able to slow down or prevent oxidative stress especially leaves extracts.

In conclusion, the present research work concludes that Ficus roxburghii is an important medicinal plant with varied 
pharmacological spectrum. Qualitative phytochemical analysis of plant parts extracts is important as it indicates the nature of phytochemicals that are possessed by such medicinal plant. The results showed that the solvent used in extraction affects the yield, total phenolic, total flavonoid, contents and their antioxidant properties in various degrees. The highest contents of phytochemical contents were obtained with methanol extracts. The estimation of phenolic and flavonoid content resulted in the highest content in the methanolic extract of leaves and fruits. From different methods of evaluating antioxidant activity, it was concluded that methanol, chloroform, ethanol, and hexane extract showed activity but methanol showed the most significant one of all extracts we can say that methanol is better solvent compared to other solvents. The in vitro antioxidant activities of the plant extracts indicate that they could be used to prevent oxidative stress and associated disorders. From all these results we can conclude that the leaves of Ficus roxburghii can be a good source of natural antioxidants in comparison to fruits. Further studies are needed for the isolation and identification of bioactive compounds responsible for antioxidant activity. The antioxidant activities of pure compounds could then be validated in vivo before clinical use.

\section{Acknowledgement}

We extend our gratitude to the Department of Biotechnology, MBGPG College Haldwani (Kumaun University), for their consistent encouragement throughout the research work.

\section{Author's contribution}

PR designed the study and wrote the manuscript. SP and PR performed the experiments. PR analyzed and verified the data.
Conflict of interest: The authors declare no conflict of interest.

\section{References}

Achi, N.K., C. Onyeabo, Ekeleme-Egedigwe, C.A. and Onyeanula, J.C. 2017. Phytochemical, Proximate analysis, vitamin and mineral composition of aqueous extract of Ficus capensis leaves in South Eastern Nigeria. J. Appl. Pharm. Sci. 7(3): 117-122.

Adebayo, E.A., O.R. Ishola, O.S. Taiwo and Majolagbe, O.N. 2009. Evaluations of the Methanolic extract of Ficus leaf, root and stem for phytochemical analysis. Afri. J. Plant Sci. 3(12): 283287.

Ahuja, J., Suresh, J., Deep, A, Madhuri, Pratyusha, and Ravi. 2011. Phytochemical screening of Aerial part of Artemisia parviflora Roxb: A medicinal plant. Der pharmacia Lettre. 3(6):116-124.

Akomolafe, S.F., G. Oboh, Oyeleye, S.I. and Boligon, A.A. 2016. Aqueous extract from Ficus capensis leaves inhibits key enzymes linked to erectile dysfunction and prevent oxidative stress in rats' penile tissue. NFS Journal. 4:15-21.

Aswar, M., U. Aswar, B. Watkar, M. Vyas and Wagh, A. 2008. Anthelmintic activity of Ficus. Int. Green Pharma. 2(3): 170-172.

Bhuiyan, M.A.R., M.Z. Hoque and Hossain, S.J. 2009. Free Radical Scavenging Activities of Zizyphus mauritiana. World J. Agr. Sci. 5: 318-322.

Brand-Williams, W., M.E. Cuvelier and Berset, C. 1995. Use of a free radical method to evaluate antioxidant activity. Lebensmittel Wissenschaft Technol, 28: 25-30.

Buniyamin, A., E.I. Ayinde, O. Fabain and Amaechina, C. 2007. Pharmacognosy and hypotensive evaluation of Ficus 
(Moraceae) leaf. Acta Polo. Pharma. 64(116): 543-546.

Cao, G., E. Sofic and Prior, R.L. 1997. Antioxidant and pro-oxidative behavior of flavonoids, structure activity relationships. Free Radical. Biol. Med. 22: 749-760.

Chatterjee, S., A. Banerjee, and Chandra, I. 2014. Hemidesmus indicus: A Rich Source of Herbal Medicine. Med. Aro. Plants. 3: e155.

Chatterjee, S., Banerjee, A. and Chandra, I. 2014. Hemidesmus indicus: A Rich Source of herbal Medicine. Med Aromat Plants. 3: e155.doi: 10.4172/21670412.1000e155.

Chatterjee, T.K. and Chakravorty, A. 1993. Wound healing properties of new antibiotic (MT81) in mice. J. Bioch. Pharmacol. 30: 450-452.

Chawla, A., R. Kaur and Sharma, A.K. 2012. Ficus: A Review on its Pharmacognostic, Phytochemical and Pharmaceutical Aspects. Int. J. Pharm. Phytopharm. Res. 1(4): 215-232.

Cushnie, T.P. and Lamb, A.J. 2005. Antimicrobial activity of flavonoids. Int. J. Antimicrob. Agents. 26(5): 343356.

David, L. and Michael, M. 2006. Freeman and Company. N Y. Principles Biochem, 45: 118-122.

Debnatha, T., P.J. Park, N.C.D. Nath, N.B. Samad, H.W. Park, and Lim, B.O. 2011. Antioxidant activity of Gardenia jasminoides Ellis fruit extracts. Food chem. 128: 697-703.

Devkota, R. and Karmacharya, S.B. 2003. Documentation of indigenous knowledge of Meidicinal plants in Gwalek, Baitadi, Nepal. Botanica Orientalis 3:135-143.

Felhi, S., Baccouch, N., Ben Salah, H., Smaoui, S., Allouche, N., Gharsallah, N. and Kadri, A. 2016a. Nutritional constituents, phytochemical profiles, in vitro antioxidant and antimicrobial properties, and gas chromatographymass spectrometry analysis of various solvent extracts from grape seeds (Vitis vinifera L.). Food Sci. Biotechnol. 25(6): 1537-1544

Gaire, B.P., Lamichhanr, R., Sunar, C.B., Shilpakar, A., Neupane, S., and Panta, S. 2011. Phytochemical screening and analysis of antibacterial and antioxidant activity of Ficus roxburghii stem Bark. J. Pharmacogn. 3(21): 49-55.

Gairola, Y. and Biswas, S. 2008. Bioprospecting in Garhwal Himalaya, Uttarakhand. Curr. Sci. 94: 1139-1144.

Gelfand, M., Mavi, S., Drummond, R.B. and Ndemera, B. 1985. The traditional medicinal practitioner in Zimbabwe. Mambo Press, Gweru, Zimbabwe. 1985; 411

Ghosh, R., Kh. Sharathchandra, Rita, S. and Thokchom, I.S. 2004. Hypoglycaemic activity of Ficus hispida (bark) in normal and diabetic albino rats. Indian Journal of Pharmacology. 36(4): 222225

Halliwell, B. and Gutteridge, J. 1999. JMC, Free Radicals in Biology and Medicine, Clarendon Press, Oxford. J. Med. Plant Res. 8(2): 676-683.

Harborne, J.B. 1973. The flavonoids: Advances in Research. Chapman and Hall, London. J. Sci. Food Agri. 3(75): 90-103.

Hasan, R.S.M., M.D. Mokarram Hossain, A. Raushanara, M.D. Mariam Ehsanul Hoque Mazumder, and Shafiqur Rahman. 2009. DPPH free radical scavenging activity of some Bangladesh medicinal plants. J. Med. Plant Res. 3(11): 875-879.

Huang, X., K.A. Yuasa, T. Norikura, D.O. Kennedy, T. Hasuma, and Yuasa, M.I. 2005. Mechanism of the anticancer activity of Zizyphus jujube in HepG2 cells. Int. J. compl. Med. East and West, 
35(3): 517-532.

Kala, C.P., 2007. Prioritization of cultivated and wild edibles by local people in the Uttarakhand hill of Indian Himalaya. Indian J. trad. Know. 6:239-244.

Kamboj, V.P., 2000. Herbal medicine. Curr. Sci. 78(1): 35-39.

Khan, S., 2001. Therapeutic plants of the Ayurveda: a review of selected clinical and other studies for 166 species. J. Alter. Compl. Med. 7(5): 405-515.

Manadhar, N.P., 1991. Medicinal plant-lore of Tamang tribe of Kavrepalanchok district, Nepal. Econ. Bot. (2): 45-58.

Mathai, K., 2000. Nutrition in the Adult Years. In Krause's Food, Nutrition, and Diet Therapy,.L.K. Mahan and S. Escott-Stump, 27: 271-274.

Mazumder, P.M., M. Farswan and Parcha, V. 2009. Hypoglycaemic effect of Ficus arnottiana Miq. Bark extracts on streptozocin induced diabetes in rats. Nat. Prod. Rad. 8(5): 478-482.

Meir, S., Kanner, J., B. Akiri and Hada, S.P. 1995. Determination and involvement of aqueous reducing compounds in oxidative defense system of various senescing leaf. J. Agri. Food chem. 43: 1813-1819.

Miller, N.J., C. Rice-Evans and Paganga, G. 1997. Antioxidant properties determind by ABTS radical assy. Free radical res. 26: 195-199.

Mpiana, P.T., Mudogo, V., Tshibangu, D.S.T., Kitwa, E.K., Kanangila, A.B., Lumbu, J.B.S., Ngbolua, K.N., Atibu EK, Kakule MK. 2008. Antisickling activity of anthocyanins from Bombax pentadrum, Ficus capensis, Zizyphus mucronata: Photo degradation effect. J. Ethnopharmacol. 120: 413-418.

Naima, R., M. Dumam, H. Hannache, A. Sesbou, B. Charrier, Pizzi, A. and Charrier-El Bouhtoury, F. 2015. Comparison of the impact of different extraction methods on polyphenols yields and tannins extracted from Moroccan Acacia mollissima barks. Ind. Crops Prod. 70: 245-252.

Njoku-Oji, N.N., C.V. Nwike, U. Dimkpa, N.O. Ifegwu, L.C. Anike, S.O. Maduka, Sobanke, O.A. and Uchefuna, R.C. 2016. Hematological changes following oral administration of aqueous leaf extract of Ficus capensis in albino rats. Int. Blood Res. Reviews. 5(1): 1-7.

Otitoju, G.T.O., Nwamarah, J.U., Otitoju, O., and Iyeghe, L.U. 2014. Nutrient composition of some lesser known green leafy vegetables in Nsukka L.G.A of Enugu State. J Biodivers Environ Sci. 4(4):233-239

Owolabi, O.J., Z.A. Nworgu, A. Falodun, Ayinde, B.A. and Nwako, C.N. 2009. Evaluation of tocolytic activity of ethanol extract of the Stem bark of Ficus capensis Thunb. (Moraceae). Acta Pol. Pharm. 66(3):293-296.

Oyeleke, S.B., Dauda, B.E.N. and Boye, O.A. 2008. Antibacterial activity of Ficus capensis. Afri. J. Biotechnol. 7(10):1414-1417.

Pan, Y., K. Wang, S.Q. Huang, H.S. Wang, X.M. Mu, C.H. He, X.W. Ji, J. Zhang and Huang, F.J. 2008. Antioxidant activity of microwave-assisted extract of longan. (Dimocarpus Longan Lour.) peel. Food Chem. 106(3): 1264-1270.

Pant, S., S.S. Samant and Arya, S.C. 2009. Diversity and indigenous household remedies of the inhabitants surrounding Mornaula reserve forest in West Himalaya. Indian J. Tradit. Know. 8(4): 606-610.

Perumalla, A.V.S., Hettiarachchy, N.S. and Ricke, S.C. 2011. Current perspectives in poultry preharvest food safty. In Direct fed microbials/prebiotics for animals: science and mechanisms of action. Ethnopharmacol. 78(7): 89-120.

Ramawat, K.G., Dass, S. and Mathur, M. 2009. The Chemical Diversity of 
Bioactive Molecules and Therapeutic Potential of Medicinal Plants. Herbal Drugs: Ethnomed. Modern Med, Springer- Verlag Berlin Heidelbergs.

Ramde-Tiendrebeogo, A., A. Tibiri, A. Hilou, O.M. Lomp, H. Millogo-Kone, Nacoulma, O.G. and Guissou, I.P. 2012. Antioxidative and antibacterial activities of phenolic compounds from Ficus sur Forssk. and Ficus sycomorus L. (Moraceae): Potential for sickle cell disease treatment in Burkina Faso. Int. J. Biol. Chem. Sci. 6(1):328-336

Rauha, J. Remes, S. and Heinonen, M. 2002. Antimicrobial effects of Finnish plant extracts containing flavonoids and other phenolic compounds. Indus. J. Food Microbiol. 56: 3-12.

Re, Raina, A.K. and Perry, 1999. Antioxidant properties determind by ABTS radical assay. Free radical Res. 26: 195-199.

Rout, S.D., Panda, T. and Mishra, N. 2009. Ethnomedicinal plants used to cure different diseases by tribal's of Mayurbhanj district of North Orissa. Ethno-Med. 3(1): 27.

Ruwali, P., Ambwani, T.K. and Gautam, P. 2017. In vitro antioxidative potential of Artemisia indica willd. Indian J. Animal Sci. 87(11): 1326-1331.

Ruwali, P., Ambwani, T.K., Gautam, P. and Thapliyal, A. 2015. Qualitative and quantitative phytochemical analysis of Artemisia indica Willd. J. Chem. Parm. Res. 7: 942-949.

Salem, M.Z.M., Salem, A.Z.M., Camacho, L.M. and Ali, H.M. 2013. Antimicrobial activities and phytochemical composition of extracts of Ficus species: An over view. Afr. J. Microbiol. Res. 7(33): 4207-4219.

Sies, H. 1997. Oxidative stress: Oxidants and antioxidants. Exp-Physiol. 82(2): 291295.

Silva, C.P.D., M.S.B. Sousa, E.S. Siguemoto, Soares, R.A.M. and Areas, J.A.G. 2014.
Chemical composition and antioxidant activity of jatoba-do-cerrado (Hymenaea stigonocarpa Mart.) flour. J. Food Sci. Technol. 34(3): 597-603.

Silva, R.A., Lima, M.S.F., Viana, J.B.M., Bezerra, V.S., Pimentel, M.C.B., Porto, A.L.F., Cavalcante, M.T.H. and Lima Filho, J.L. 2012. Can Artisanal "Coalho" Cheese from Northeastern Brazil Be Used as a Functional Food. Food Chem. 135: 1533-1538.

Singleton, V.L. and Rossi, JA. Jr. 1965. Colorimetry of total phenolics with phosphomolybdic - Phosphotungstic and ragent. Amer. J. Enol. Vitical, 16: 144-158.

Sisa, M., Bonnet, S.L., Ferreira, D. and van der Westhuizen, J. H. 2010. Photochemistry of flavonoids. Molecules. 15: 5196-5245.

Sofowara, A. 1982. Medicinal plants and traditional medicinal in Africa. New York: John Wiley and Sons. J. Biol. Sci. 41: 154-176.

Spencer and Jeremy, P.E. 2008. "Flavonoids: modulators of brain function?". Br. J. Nut. 99 : ES60-7. Doi:10.1017/S0007114508965776.

Tandon, V. (1996). Med. Plant Conserv. Newsl, 2: 12-13.

Thingbaijam, R., Dutta, B.K. and Paul, S.B. 2012. In vitro antioxidant capacity, estimation of total phenolic and flavonoid content of Ficus roxburghii. Int. J. Pharm. Pharm. Sci. 4(4): 518521.

Thingbaijam, R., Dutta, B.K. and Satya, B.P. 2013. Antihyperglycemic and Antihyperlipidemic activity of Ficus roxburghii. Leaf Extract in Streptozotocin Induced Diabetic Mice. World J. Pharm. Pharm. Sci. 3 (1): 412427.

Umeokoli, B.O., F.A. Onyegbule, Gugu, T.H. and Igboeme, S.O. 2013. Evaluation of the erythropoietic and anti-sickling 
properties of Ficus capensis leaf extract in the treatment of anaemia. Planta Medica. 79 -PE29.

Yakubu, M.T., Akanji, M.A. and Oladiji, A.T. 2005. Aphrodisiac potentials of the aqueous extract of Fadogia agrestis (Schweinf. Ex Hiern) stem in male albino rats. Asian J. Androl. 7(4): 399404.

Zhishen, J., Mengcheng, T. and Jianming, W. 1999. The determination of flavonoid contents in mulberry and their scavenging effects on superoxide radicals. Food chem. (65): 555-559.

\section{How to cite this article:}

Pushpa Ruwali and Sarita Pateliya. 2019. The Difference of Solvent Polarity to Qualitative and Quantitative Phytochemical Contents and Antioxidant Activity of Ficus roxburghii Wall. Leaves and Fruits Extracts. Int.J.Curr.Microbiol.App.Sci. 8(04): 1724-1741.

doi: https://doi.org/10.20546/ijcmas.2019.804.202 